Chapman University

Chapman University Digital Commons

Law Faculty Articles and Research

Fowler School of Law

1984

\title{
The Doctrine of Conditional Preemption and Other Limitations on Tenth Amendment Restrictions
}

Ronald D. Rotunda

Chapman University, Fowler School of Law, rrotunda@chapman.edu

Follow this and additional works at: http://digitalcommons.chapman.edu/law_articles

Part of the Constitutional Law Commons, and the State and Local Government Law Commons

\section{Recommended Citation}

Ronald D. Rotunda, The Doctrine of Conditional Preemption and Other Limitations on Tenth Amendment Restrictions, 132 U. PA. L. REv. 289 (1984).

Available at: http://digitalcommons.chapman.edu/law_articles/15

This Article is brought to you for free and open access by the Fowler School of Law at Chapman University Digital Commons. It has been accepted for inclusion in Law Faculty Articles and Research by an authorized administrator of Chapman University Digital Commons. For more information, please contact laughtin@chapman.edu. 


\title{
THE DOGTRINE OF CONDITIONAL PREEMPTION AND OTHER LIMITATIONS ON TENTH AMENDMENT RESTRICTIONS
}

\author{
RONALD D. ROTUNDA $†$
}

\section{INTRODUCTION}

Before the middle of the 1970's, it appeared to be a settled principle of modern American constitutional law that the tenth amendment failed to limit Gongress's power under the commerce clause. In 1941, the Supreme Court characterized the tenth amendment as a "truism"1 of little practical importance, concluding that "there is nothing in the history of its adoption to suggest that it was more than declaratory of the relationship between the national and state governments."2 This restrictive view echoed even earlier interpretations of the tenth amendment as a mere constitutional redundancy ${ }^{3}$ and was prophetic of the Court's interpretation of federalism principles for nearly four decades.

Following Franklin D. Roosevelt's Court-packing proposal, ${ }^{*}$ the Supreme Court began to acknowledge that the nation's economic and social problems called for national solutions, and that the Constitution did not forbid such a federal role. Congress responded by enacting a plethora of federal legislation imposing significant obligations on the states, "federalizing" the machinery of state government to serve the ends of national policy. From 1937 until 1976, the Court consistently rejected tenth amendment attacks on this congressional regulation of the activities of state and local government entities when those challenges

† Professor of Law, University of Illinois. B.A. 1967, J.D. 1970, Harvard University. The author wishes to thank Christine Charysh and Jody McPherson for their helpful research assistance.

1 United States v. Darby, 312 U.S. 100, 123-24 (1941).

2 Id. at 124. This historical assessment is illustrated by James Madison's attempt in The Federalist Papers to calm the apprehension voiced by states' rights advocates during the ratification debates that the states as political entities would be obliterated by the powers of the federal government. THE FEDERALIST No. 45 (J. Madison).

3 As Chief Justice Marshall noted over 150 years ago, the tenth amendment had been framed merely "for the purpose of quieting the excessive jealousies which had been excited." McCulloch v. Maryland, 17 U.S. (4 Wheat.) 316, 406 (1819).

4 For a discussion of the Court-packing plan, see L. BAKER, BACK To BACK, ThE Duel Between FDR and the Supreme Court (1967); R. Jackson, The StrugGLE FOR JUDICIAL SUPREMACY (1941); Leuchtenberg, The Origins of Franklin $D$. Roosevelt's "Court-Packing Plan," 1966 Sup. CT. REv. 347; Mason, Harlan Fiske Stone and FDR's Court Plan, 61 YALE L.J. 791 (1952). 
were based on an asserted interest in state autonomy. ${ }^{\circ}$ The tenth amendment, according to the Court, lacked a specific or enforceable guarantee that might check the broadly interpreted federal commerce power. ${ }^{6}$ The Supreme Court engaged in simply pro forma review, with toothless scrutiny of Congress's exercise of the commerce power. ${ }^{7}$ By the mid-1970's, the tenth amendment was reduced to a mere expression of sentiment whose time had passed. Then in June 1976, for the first time since the Court-packing plan, the Supreme Court, in National League of Cities $v$. Usery, ${ }^{8}$ used tenth amendment principles to invali-

S See, e.g., Fry v. United States, 421 U.S. 542, 548 (1975) (Court upholds the Economic Stabilization Act of 1970 application of wage and salary freezes to state employees. Court rejects state sovereignty argument, stating that sovereign status does not render states immune from federal regulation.); Maryland v. Wirtz, 392 U.S. 183 (1968) (Court upholds extension of the Fair Labor Standards Act to employees of state hospitals, institutions, and schools. Extension subjected these employees to federal minimum wage and hour requirements. Court dismisses argument that the tenth amendment and principle of state sovereignty existed as a limitation on congressional power under commerce clause.), overruled in National League of Cities v. Usery, 426 U.S. 833 (1976); California v. Taylor, 353 U.S. 553 (1957) (Railway Labor Act requires collective bargaining between a state and its civil servants working on state-owned railroads because a state as well as a private person could disrupt commerce. Court not receptive to state sovereignty claim.).

- See, e.g., United States v. Darby, 312 U.S. 100, 123-24 (1941) (upholding application of Fair Labor Standards Act to local manufacturing activities; "the [tenth] amendment states but a truism") See generally J. NowAK, R. RoTUNDA \& J. YOUNG, Constitutional. Law 161-70 (2d ed. 1983).

7 For an example of the minimum scrutiny the Court gave to commerce power cases after 1937, see Perez v. United States, 402 U.S. 146 (1971). In Perez a federal statute, 18 U.S.C. $\$ \S 891-896$ (1976), which made "loansharking" a crime was applied to petitioner, a "loanshark" in New York, who used threats of violence to collect $\$ 3000$ he had loaned to a local butchershop. The Court affirmed the conviction, stating that there was "a tie-in between local loansharks and interstate crime." 402 U.S. at 155. In dissent, Justice Stewart stated that loansharking was no different from other local crime and thus, the statute was beyond the power of Congress. He stated that "the definition and prosecution of local, intrastate crime are reserved to the States under the Ninth and Tenth Amendments." Id. at 158 (Stewart, J., dissenting). See also Katzenbach v. McClung, 379 U.S. 294 (1964) (Title II of the Civil Rights Act of 1964, as applied to a restaurant receiving about $\$ 70,000$ worth of food which had moved in commerce, was held to be a valid exercise of the commerce power. Although Ollie's Barbecue had very few, if any, interstate travellers as patrons, it was held to be subject to the Act because discrimination causes a loss of black patronage. That loss of patronage results in less food being sold which causes less food to move in interstate commerce. The Supreme Court ignored the district court's finding that serving blacks at Ollie's would cause a loss of business and thus less food would move in interstate commerce.); Hamm v. Rock Hill, 379 U.S. 306 (1964) (Court applies Civil Rights Act of 1966 to vacate state trespass convictions for lunch counter "sit-ins" by civil rights workers; the Court upheld the law on commerce clause grounds and applied it to the state trespass convictions rendered, but not finalized, prior to the law's passage. Justice Harlan said in dissent: "[T] state trespass convictions would result in placing any burden on present interstate commerce." 379 U.S. at 325 (Harlan, J., dissenting) (footnote omitted)).

8426 U.S. 833 (1976). 
date an act of Congress, seemingly resurrecting a state sovereignty limitation on the federal commerce power.

National League of Cities provoked scholarly commentary expressing fears that the Court was reverting to its pre-1937 unprincipled approach to the problem of the proper limitations on federal commerce power. ${ }^{\circ}$ Yet, in the seven years since National League of Cities, no Supreme Court opinion has used the tenth amendment to invalidate federal legislation, and several subsequent cases have, in fact, severely restricted the growth of the National League of Cities approach. This paper explores these post-National League of Cities decisions, in particular, Federal Energy Regulatory Commission v. Mississippi, ${ }^{10}$ and concludes that although National League of Cities may still stalk the night in prey of federal statutes to invalidate, its claws are dulled and its size has much diminished.

\section{The Rediscovery of the Tenth Amendment: National League of Cities $v$. Usery}

In National League of Cities $v$. Usery ${ }^{11}$ the issue was whether the commerce clause empowers Congress to regulate the states and their political subdivisions in the area of employer-employee relations. Several cities and states had brought suit against the Secretary of Labor, challenging the validity of the 1974 amendments $^{12}$ to the Fair Labor

- See, e.g., Cox, Federalism and Individual Rights under the Burger Court, 73 Nw. U.L. REv. 1, 22 (1978) ("[A]lthough the decision in National League of Cities is almost surely consistent with the original conception of the federal union and might not have surprised any constitutional scholar prior to the 1930's, it is thoroughly inconsistent with the constitutional trends and decisions of the past forty years." Cox states "that National League of Cities will come to be seen as no more than an unprincipled exception to the general rule of federal supremacy."); Matsumoto, National League of Cities-From Footnote to Holding-State Immunity from Commerce Clause Regulation, 1977 ARIz. ST. L.J. 35, 37, 89 ("The historical significance of the National League of Cities decision can be appreciated when one notes that . . the Court since 1937 has not used constitutionally-based federalistic limitations to invalidate an exercise of congressional regulatory power." Matsumoto concludes by stating that "[w]hether the Court is any better suited now than it was during the pre-1937 period to umpire between congressional and state governmental interests . . can only be judged by future developments. However, the answer to that future issue ultimately may be found in the past."); Schwartz, National League of Cities v. Usery-The Commerce Power and State Sovereignty Redivivus, 46 FordHaM L. REv. 1115, 1133-34 (1978) ("[T]he most disturbing aspect of the National League of Cities decision is the Court's gratuitous revival in it of the concept of state sovereignty." Schwartz goes on to state that "It]he evil that may be done by raising the ghost of state sovereignty may, however, outlive the immediate decision of the Court.").

10456 U.S. 742 (1982).

11426 U.S. 833 (1976).

12 Fair Labor Standards Amendments of 1974, Pub. L. No. 93-259, 88 Stat. 55 (codified as amended at 29 U.S.C. $\$ \S 201-219$ (1976)). 
Standards $\mathrm{Act}^{\mathbf{1 3}}$ and seeking declaratory and injunctive relief from the application of the Act's minimum wage, maximum hour, and overtime provisions. The amendments extended those provisions to almost all employees of public agencies. ${ }^{14}$ The cities and states contended that when the Act was applied to state and municipal employees, as opposed to private employees, it violated the tenth amendment.

Five members ${ }^{16}$ of a bitterly divided bench upheld the challenge, overruled precedent, ${ }^{16}$ and asserted that to the extent the Fair Labor amendments operated to "directly displace the States' freedom to structure integral operations in areas of traditional governmental functions, they are not within the authority granted Congress by [the commerce clause]."17

Justice Rehnquist, for the majority, readily granted that the legislation at issue was enacted pursuant to the plenary authority granted to Congress under the commerce clause. He concluded, however, that, as applied to "States qua States,"18 the legislation encountered the "constitutional barrier"18 of state sovereignty:

We have repeatedly recognized that there are attributes to sovereignty attaching to every state government which may not be impaired by Congress, not because Congress may lack an affirmative grant of legislative authority to reach the matter, but because the Constitution prohibits it from exercising the authority in that manner. ${ }^{20}$

The Court concluded that a state's power to set the wages of its

13 Fair Labor Standards Act of 1938, ch. 676, 52 Stat. 1060 (codified as amended at 29 U.S.C. $\$ \$ 201-219(1976)$ ).

14 Fair Labor Standards Amendments of 1974, Pub. L. No. 93-259, 88 Stat. 55 (codified as amended at 29 U.S.C. $\$ \S 201-219$ (1976)).

${ }^{25}$ Justice Rehnquist delivered the opinion of the Court, joined by Chief Justice Burger and Justices Stewart, Blackmun, and Powell. Justice Brennan filed a dissenting opinion in which Justices White and Marshall joined. Justice Stevens wrote a separate dissenting opinion. Although he wrote a separate concurring opinion, Justice Blackmun also joined the majority opinion. Several courts and commentators have erroneously characterized the majority decision as a plurality opinion. See, e.g., United Transp. Union v. Long Island R.R., 634 F.2d 19, 24 (2d Cir. 1980), rev'd, 455 U.S. 678 (1982).

16426 U.S. at 855. The Court expressly overruled Maryland v. Wirtz, 392 U.S. 183 (1968), in which the Court had upheld the 1966 amendments to the Fair Labor Standards Act that extended the Act's coverage to include employees of state hospitals, institutions, and schools.

17426 U.S. at 852 . Fire prevention, police protection, sanitation, protection of public health, and maintenance of parks and recreation facilities were enumerated as other examples of "traditional governmental functions." Id. at 851 .

${ }^{18} \mathrm{Id}$. at 847.

19 Id. at 841 .

20 Id. at 845. 
employees was an "undoubted attribute of state sovereignty,"21 and that the functions performed by affected state employees were "essential to separate and independent existence" of the state. ${ }^{22}$ According to Justice Rehnquist, by imposing wage and hour limits the statute could potentially force reductions in state-provided public services, as well as severely restrict the states' control over their employees. In short, "the federal requirement directly supplants the considered policy choices of the States' elected officials." 23 Such a direct interference with the states' "essential decisions"24 and ability to "structure employer-employee relationships"2s in areas involving "integral governmental functions"2B constituted a violation of the principles of federalism. ${ }^{27}$

Justice Blackmun, joining the majority as the pivotal fifth vote, also wrote a separate concurrence. He interpreted the majority opinion as advocating a balancing approach in which the burden a federal regulation imposes upon a state and the extent of interference with state autonomy is weighed ad hoc against the magnitude of the federal interest and the need for state compliance. ${ }^{28} \mathrm{He}$ also voiced his understanding, without further elaboration, that the decision would not "outlaw federal power in areas such as environmental protection, where the federal interest is demonstrably greater and where state facility compliance

21 Id.

22 Id. (quoting Coyle v. OkJahoma, 221 U.S. 559, 580 (1911) (quoting Lane County v. Oregon, 74 U.S. (7 Wall.) 71, 76 (1869))).

13 Id. at 848 .

24 Id. at 855 .

${ }^{25}$ Id. at 851 . 81.

26 Id. See generally J. Nowak, R. Rotunda \& J. Young, supra note 6, at 170 -

27 Professor Tribe has argued that National League of Cities is best understood as resting not on the tenth amendment, but rather on the desire of the Court to protect individual rights to basic governmental (state-provided) services. L. TRIBE, AMERICAN Constitutional LAw § 5-22, at 308 n.9, 313 (1978); see also Tribe, Unraveling National League of Cities: The New Federalism and Affirmative Rights to Essential Government Services, 90 HaRv. L. REv. 1065 (1977) [hereinafter cited as Tribe, Unraveling National League of Cities]. Professor (now Judge) Ruth Bader Ginsberg correctly calls this interpretation one of Tribe's "eyebrow raisers," and "extravagant." Ginsberg, Book Review, 92 HaRv. L. REv. 340, 342, 344 (1978). The only textual support mentioned in Justice Rehnquist's opinion is the tenth amendment. See $\mathrm{Na}$ tional League of Cities, 426 U.S. at 842. Neither Justice Brennan, who dissented in National League of Cities, nor Justice Rehnquist, who wrote the opinion of the Court, intimated that the purpose or effect of the decision was to give individuals some kind of constitutional right to demand state services.

Moreover, the Court itself has not hesitated to characterize National League of Cities as a case resting on the tenth amendment. See Federal Energy Regulatory Comm'n v. Mississippi, 456 U.S. 742, 758-71 (1982); id. at 778-79 (O’Connor, J., joined by Burger, $C . J_{.}$and Rehnquist, $J$, concurring in the judgment in part and dissenting in part).

${ }^{28} 426$ U.S. at 856 (Blackmun, J., concurring). 
with imposed federal standards would be essential."29 Several lower courts and commentators quickly adopted Blackmun's balancing approach as the correct interpretation of the decision. ${ }^{30}$

Justice Brennan, in a dissent joined by Justices White and Marshall, vigorously attacked the fundamental basis of the majority opinion. Echoing Wechsler's theory of political safeguards, ${ }^{31}$ Brennan asserted that the popularly elected branches are the only appropriate forum for the resolution of such federalism questions. He caustically termed the majority's attempt to protect state autonomy a "patent usurpation of the role reserved for the political process."32 Brennan's dissent, characterizing the majority's tenth amendment analysis as "an abstraction without substance, founded neither in the words of the Constitution, nor on precedent," 33 condemned the majority for engaging in unabashed policymaking and for exploiting their judicial robes by manufacturing a lengthy legal argument merely as "a transparent cover for invalidating a congressional judgment with which they disagree."34 The dissent also found insurmountable practical obstacles to the application of the "traditional government functions" test Rehnquist had enunciated. "[T]hat the test is unworkable," Brennan stated, "is demonstrated by my Brethren's inability to articulate any meaningful distinctions among state-operated railroads . . . state-operated schools and hospitals, and state-operated police and fire departments."3s

Justice Stevens apparently agreed that the "traditional governmental functions" test was unworkable. He wrote a separate dissent argu-

29 $I d$.

so See, e.g., Woods v. Homes \& Structures, Inc., 489 F. Supp. 1270, 1296-97 (D. Kan. 1980) (balancing federal interest in requiring bond issues to comply with federal antifraud provisions against local governments' power to issue bonds); Colorado v. Veterans Admin., 430 F. Supp. 551, 559 (D. Colo. 1977) (federal interest in monitoring veterans educational benefits program balanced against interference with state educational institutions), aff d, 602 F.2d 926 (10th Cir. 1979), cert. denied, 444 U.S. 1014 (1980); see also Barber, National League of Cities v. Usery: New Meaning for the Tenth Amendment?, 1976 SuP. CT. REv. 161, 164 (National League of Cities "would thus transport us from a regime which has sacrificed states' sovereignty for congressional supremacy to a regime in which the Court will balance states' rights against interests represented by Congress."); Note, Practical Federalism After National League of Cities: A Proposal, 69 GEO. L.J. 773, 780 (1981) ("the majority's treatment of Fry and Justice Blackmun's concurrence point to the conclusion that [National League of Cities v.] Usery employs a balancing test that evaluates affected federal and state interests and examines the suitability of the chosen means to accomplish the federal end").

${ }^{31}$ See Wechsler, The Political Safeguards of Federalism: The Role of the States in the Composition and Selection of the National Government, 54 Colum. L. REv. 543 (1954), cited in National League of Cities, 426 U.S. at 877 (Brennan, J., dissenting).

32426 U.S. at 858 (Brennan, J., dissenting).

$38 \mathrm{Id}$. at 860 .

se Id. at 867 .

ss Id. at 880 . 
ing that he was "unable to identify a limitation on [the commerce power] that would not also invalidate federal regulation of state activities that [he considered] unquestionably permissible."36

Brennan's dissent characterized the majority holding in National League of Cities as a "portent . . . so ominous for our constitutional jurisprudence as to leave one incredulous." constitutional law as well as members of the judiciary agreed, for $\mathrm{Na}$ tional League of Cities precipitated extraordinarily broad and severe criticism and comment. ${ }^{38}$

\section{Judicial Limitations on National League of Cities v. Usery PrIor to FERC v. Mississippi}

The Court's resurrection of state sovereignty limitations on congressional power spawned a controversy that some observers soon thought to have been overrated. ${ }^{38}$ What many initially had perceived as a radical departure from existing tenets of constitutional law was described in one lower court's revisionist view of history as "a very carefully worded opinion on a very narrow issue."40 Other cases have, with more clarity, severely diminished the impact of National League of Cities $v$. Usery ${ }^{41}$ by limiting its parameters and restricting its implications.

so Id. at 881 (Stevens, J., dissenting).

97 Id. at 875 (Brennan, J., dissenting).

38 See, e.g., Beaird \& Ellington, A Commerce Power Seesaw: Balancing National League of Cities, 11 GA. L. REv. 35 (1976); Choper, The Scope of National Power Vis-a-Vis the States: The Dispensability of Judicial Review, 86 YALE L.J. 1552 (1977); Cox, Federalism and Individual Rights under the Burger Court, 73 Nw. U.L. REv. 1 (1978); Heldt, The Tenth Amendment Iceberg, 30 Hastrngs L.J. 1763 (1979); Michelman, States' Rights and States' Roles: Permutations of "Sovereignty" in National League of Cities v. Usery, 86 YALE L.J. 1165 (1977); Stewart, Pyramids of Sacrifice? Problems of Federalism in Mandating State Implementation of National Environmental Policy, 86 YaLE L.J. 1196 (1977); Tribe, Unraveling National League of Cities, supra note 27; Tushnet, The Dilemmas of Liberal Constitutionalism, 42 OHIO ST. L.J. 411, 420-21 (1981); Note, Practical Federalism After National League of Cities: A Proposal, 69 Geo. L.J. 773 (1981); Note, supra note 30.

39 See, e.g., Barber, supra note 30, at 165 ("The doctrine of League of Cities may not survive."); Choper, supra note 38, at 1596-97 (National League of Cities v. Usery, 426 U.S. 833 (1976), "parallels the once greatly inflated, but now severely contracted strictures on Congress's power to tax." (footnote omitted)); Cox, supra note 38, at 22 ("National League of Cities will come to be seen as no more than an unprincipled exception to the general rule of federal supremacy."); Note, Federal Securities Fraud Liability and Municipal Issuers: Implications of National League of Cities v. Usery, 77 Colum. L. Rev. 1064, 1069 (1977) ("The Usery case . . . stands unequivocally only for the rather vague proposition that there are some limits on federal power to regulate the means by which states perform their traditional functions.").

Pa. 1980).

to EEOC v. Pennsylvania Liquor Control Bd., 503 F. Supp. 1051, 1053 (M.D.

41426 U.S. 833 (1976). 


\section{A. Spending Power, War Powers, and the Power Under Section 5 of the Fourteenth Amendment}

On its own terms, National League of Cities applies only to statutes enacted under Congress's commerce power. In a footnote the Court cautioned, without explanation, that it expressed "no view as to whether different results might obtain if Congress seeks to affect integral operations of state governments by exercising authority granted it under sections of the Constitution such as the spending power, Art. I, $\S$ 8, cl. 1 , or $\S 5$ of the Fourteenth Amendment."42 The majority further limited its holding by stating that "[n]othing we say in this opinion addresses the scope of Congress' authority under its war power."43

In light of these qualifications, National League of Cities has been interpreted as an attempt to limit solely Congress's power under the commerce clause. Many lower courts, subsequently faced with tenth amendment challenges to federal legislation enacted pursuant to the spending power, war powers, or the enabling clause of the fourteenth amendment, have, therefore, announced that the National League of Cities analysis is simply inapplicable. ${ }^{44}$

Lower courts have recognized that the intrusive and exacting conditions imposed by some federal spending programs offend the same state interests purportedly protected by National League of Cities in the commerce power context. Nonetheless, these courts have continued to allow federal ${ }^{*}$ interference with state sovereignty after National League of Cities when the interference stems from Congress's exercise of the spending power. In such cases, the state has a choice whether or not to participate in federally funded programs, even if this "choice" is often illusory because the federal "bribe" is so large. For example, courts have permitted federal grant programs to dictate certain state governmental structures as a condition for receiving financial aid, provided the grant program was "voluntary."

42 Id. at 852 n.17.

4s Id. at 855 n.18.

44 See, e.g., New Hampshire Dep't of Employment Sec. v. Marshall, 616 F.2d 240, 247 (1st Cir.) (spending power), appeal dismissed, 449 U.S. 806 (1980); Walker Field, Colo. Pub. Airport Auth. v. Adams, 606 F.2d 290, 297-98 (10th Cir. 1979) (spending power); Jennings v. Illinois Office of Educ., 589 F.2d 935, 938 (7th Cir.) (war powers), cert. denied, 441 U.S. 967 (1979); Marshall v. Delaware River \& Bay Auth., 471 F. Supp. 886, 891-92 (D. Del. 1979) (fourteenth amendment); North Carolina ex rel. Morrow v. Califano, 445 F. Supp. 532, 536 n.10 (E.D.N.C. 1977) (spending power), affd mem., 435 U.S. 962 (1978); City of Philadelphia v. SEC, 434 F. Supp. 281, 287-88 (E.D. Pa. 1977) (spending power), appeal dismissed, 434 U.S. 1003 (1978).

1s See, e.g., Montgomery County v. Califano, 449 F. Supp. 1230 (D. Md. 1978), affd mem., 599 F.2d 1048 (4th Cir. 1979); Florida Dep't of Health and Rehabilitative 
the Supreme Court would interfere with these post-National League of Cities lower court decisions, and Bell $v$. New Jersey, ${ }^{46}$ a unanimous 1983 decision, reaffirms their rationale.

Bell held that the federal government may recover funds that were misused after being advanced to a state as part of a federal grant-in-aid program. ${ }^{47}$ Justice O'Connor, speaking for the Court, reasoned that recouping the money from the state does not violate the tenth amendment because:

Requiring States to honor the obligations voluntarily assumed as a condition of federal funding before recognizing. their ownership of funds simply does not intrude on their sovereignty. The State chose to participate in the Title I program and, as a condition of receiving the grant, freely gave its assurances that it would abide by the conditions of Title I. $^{48}$

The Court's consistent restraint and deference in cases involving Congress's war powers also stand in contrast to the National League of Cities approach to the commerce clause. The Court, even before it began exercising deference in the interstate commerce area, traditionally had engaged in a deferential review of statutes enacted under the war powers, including those directly affecting state governmental activities. In the leading pre-National League of Cities decision of Case $v$. Bowles, ${ }^{19}$ the Court sustained an application of the Emergency Price Control Act ${ }^{\mathrm{sO}}$ to a sale of timber by the state of Washington, expressly noting that the "only question is whether the State's power to make the

Servs. v. Califano, 449 F. Supp. 274 (N.D. Fla.), affd mem., 585 F.2d 150 (5th Cir. 1978), cert. denied, 441 U.S. 931 (1979); see also Comment, Toward New Safeguards on Conditional Spending: Implications of National League of Cities v. Usery, 26 AM. U.L. REv. 726 (1977).

403 S. Ct. 2187 (1983).

47 Title I of the Elementary and Secondary Education Act of 1965 (ESEA), Pub. L. No. 89-10, 79 Stat. 27 (codified as amended, 20 U.S.C. $\$ \S 2701-2854$ (Supp. V 1981)).

Title I created a program to improve educational opportunities for disadvantaged children. Local educational agencies obtain federal grants through state educational agencies, which, in turn, receive their grants from the Department of Education on the assurance that the funds will be spent by the local agencies only on qualifying programs. Bell, 103 S. Ct. at 2189-90.

18103 S. Ct. at 2197 (emphasis added). Federal Energy Regulatory Comm'n v. Mississippi, 456 U.S. 742 (1982), in effect affirms and rationalizes the inapplicability of National League of Cities to the spending clause, because the restrictions attached to such federal grants are analogous to the conditional preemption in FERC. See infra text accompanying notes 151-56.

10 327 U.S. 92 (1946).

so Emergency Price Control Act of 1942, ch. 26, 56 Stat. 23 (expired). 
sales must be in subordination to the power of Congress to fix maximum prices in order to carry on war." 51 The Court rejected the state's claim of immunity because sustaining the state's position would impermissibly "impair a prime purpose of the Federal Government's establishment." tional grant of war powers is sufficient to sustain a statute that might otherwise violate the tenth amendment. ${ }^{\text {s3 }}$

The authority of Case was not affected by National League of Cities. In a footnote to the majority opinion, Justice Rehnquist explicitly stated that Case was not being overruled and that nothing in $\mathrm{Na}$ tional League of Cities was intended to address the scope of congressional prerogatives under the war powers. ${ }^{54}$ Thus, subsequent lower court cases, almost without exception, ${ }^{\text {so }}$ have held that the National League of Cities test is inapplicable to a statute enacted under the war powers. ${ }^{\text {sB }}$

The National League of Cities majority also expressly disclaimed any intention to rule on the constitutionality of the exercise of congressional power against the states pursuant to section 5 of the fourteenth amendment. ${ }^{57}$ Over a century ago, the Court enunciated what has come to be regarded as its traditional stance on that issue: "The prohibitions of the Fourteenth Amendment are directed to the States, and they are to a degree restrictions of State power. Such enforcement is no invasion of State sovereignty." Ons Only four days after it decided National League of Cities, the Court unanimously reaffirmed its adherence to this line of analysis in Fitzpatrick $v$. Bitzer. ${ }^{59}$ In Fitzpatrick, the Court upheld the validity of the 1972 extension of Title VII of the Civil Rights $\mathrm{Act}^{\mathrm{B0}}$ to state and local government employees. Specifically, the Court determined that the eleventh amendment and the principle of state sovereignty it embodies are limited by the enforcement provision

327 U.S. at 102.

52 Id.

ss Accord United States v. Oregon, 366 U.S. 643, 648-49 (1961).

s4 National League of Cities, 426 U.S. at 854 n.18.

so One court has held National League of Cities' federalism policies must at least be considered when the exercise of war powers interferes with state and local governmental functions. Peel v. Florida Dep't of Transp., 600 F.2d 1070, 1083 (5th Cir. 1979).

${ }^{\text {se }}$ See, e.g., Jennings v. Illinois Office of Educ., 589 F.2d 935, 938 (7th Cir.), cert. denied, 441 U.S. 967 (1979); $c f$. United States Postal Serv. v. Brennan, 574 F.2d 712, 716 (2d Cir. 1978) (postal power), cert. denied, 439 U.S. 1115 (1979).

${ }^{37} 426$ U.S. at 852 n.17, quoted supra text accompanying note 42.

s8 Ex parte Virginia, 100 U.S. 339, 346-47 (1879).

so 427 U.S. 445 (1976).

60 Equal Employment Opportunity Act of 1972, Pub. L. No. 92-261, 86 Stat. 103 (codified as amended at 42 U.S.C. $\$ \S 2000$ e to 2000 e-17 (1976 \& Supp. IV 1980)). 
of the fourteenth amendment. ${ }^{61}$ Authoring this opinion, as he had $\mathrm{Na}$ tional League of Cities, Rehnquist reasoned:

In [\$ 5] Congress is expressly granted authority to enforce "by appropriate legislation" the substantive provisions of the Fourteenth Amendment, which themselves embody significant limitations on state authority. When Congress acts pursuant to $\S 5$, not only is it exercising legislative authority that is plenary within the terms of the constitutional grant, it is exercising that authority under one section of a constitutional amendment whose other sections by their own terms embody limitations on state authority. ${ }^{62}$

Although Fitzpatrick dealt with the federal government's right to infringe upon the state's rights protected by the eleventh amendment, ${ }^{63}$ not the tenth, its message was clear: if federal legislation is properly founded on section 5 of the fourteenth amendment, it may infringe on attributes of state sovereignty protected by other constitutional amendments which the fourteenth amendment, by its own terms, was meant to affect. $^{\text {.4 }}$

The Court reaffirmed this message in Milliken $v$. Bradley, $^{85}$ a school desegregation case upholding a federal court's remedial order despite its substantial impact on the state treasury. Relying on Fitzpatrick, the Court held that the "Tenth Amendment's reservation of nondelegated powers to the States is not implicated by a federal-court judgment enforcing the express prohibitions of unlawful state conduct enacted by the Fourteenth Amendment." ${ }^{\text {"6s }}$ Later cases confirm this principle. $^{67}$

62427 U.S. at 456.

62 Id.

6s The eleventh amendment provides that "[ $t]$ he judicial power of the United States shall not be construed to extend to any suit in law or equity, commenced or prosecuted against one of the United States by Citizens of another state, or by Citizens or Subjects of any Foreign State." U.S. ConST. amend. XI.

64 Usery v. Charlestown County School Dist., 558 F.2d 1169 (4th Cir. 1977); Usery v. Allegheny County Inst. Dist., 544 F.2d 148, 155 (3d Cir. 1976), cert. denied, 430 U.S. 946 (1977); EEOC v. Pennsylvania Liquor Control Bd., 503 F. Supp. 1051, 1053 (M.D. Pa. 1980); Marshall v. Delaware River \& Bay Auth., 471 F. Supp. 886, 891-92 (D. Del. 1979).

6s 433 U.S. 267 (1977).

${ }^{68} \mathrm{Id}$. at 291.

67 See, e.g., Fullilove v. Klutznick, 448 U.S. 448, 476 (1980) (Burger, C.J., announced the judgment of the Court in an opinion joined by White \& Powell, JJ.) (under the fourteenth amendment Congress can "regulate the procurement practices of state and local grantees of federal funds"); $c f$. Rome v. United States, 446 U.S. 156, 179-80 (1980) (fifteenth amendment also overrides state sovereignty limitations). 


\section{B. The Post-National League of Cities Supreme Court Litigation}

In addition to the express limitations on its holding in the $\mathrm{Na}$ tional League of Cities opinion itself, recent Supreme Court decisions indicate the Court's desire to further cabin National League of Cities. These cases severely restrict the reach of National League of Cities even in situations where Congress has sought to reach intrastate activities under its commerce power. Although these cases suggest a general retreat from the full breadth of National League of Cities, the two most recent cases discussed below ${ }^{68}$ may portend a return to sweeping Court review of congressional actions under the commerce power.

\section{Hodel v. Virginia Surface Mining and Reclamation Association, Inc.}

The Supreme Court's first opportunity to clarify the implications of its dramatic pronouncements in National League of Cities came as a result of tenth amendment challenges to provisions of the Surface Mining Control and Reclamation Act of 1977 (SMCRA). ${ }^{69}$ Hodel v. Virginia Surface Mining and Reclamation Association, Inc. ${ }^{70}$ limited $\mathrm{Na}$ tional League of Cities by making clear that the tenth amendment does not restrict Congress's power to preempt or displace state regulation of private activity.

The SMGRA is a comprehensive statute designed to provide national performance standards for the coal mining industry in an effort to protect the environment from the adverse effects of surface coal mining operations without unduly discouraging coal production. The Act is a detailed regulatory program promulgated to ensure that surface mining is conducted with minimal disturbance to the landscape. ${ }^{71}$ The SMCRA invites the states to submit their own reclamation plans for approval by the Secretary of Interior; ${ }^{22}$ the Secretary, however, is empowered to promulgate and implement federal "plans" in those states

68 EEOC v. Wyoming, 103 S. Ct. 1054 (1983); Federal Energy Regulatory Comm'n v. Mississippi, 456 U.S. 742 (1982); see infra text accompanying notes 115237.

60 Pub. L. No. $95-87,91$ Stat. 445 (codified as amended at 30 U.S.C. $\S \S 1201$ 1328 (Supp. V 1981)).

70 452 U.S. 264 (1981).

71 SMCRA $\S 102(d), 30$ U.S.C. $\S 1202$ (d) (Supp. V 1981) ("It is the purpose of this Act . . . (d) to assure that surface coal mining operations are so conducted as to protect the environment.").

${ }^{72}$ Id. $\S 503,30$ U.S.C. $\S 1253$ (a) (Supp. V 1981). 
electing not to formulate such programs on their own initiative. ${ }^{73}$ If the states do not act, the federal government will. ${ }^{74}$

The lower courts in Virginia Surface Mining and Reclamation Association, Inc. v. Andrus ${ }^{76}$ and Indiana v. Andrus ${ }^{76}$ had found that certain provisions of the SMCRA impermissibly preempted the state's legislative discretion over areas of traditionally local concern in contravention of the tenth amendment. In both cases, the district court had relied extensively upon National League of Cities for its reasoning and conclusion; ${ }^{77}$ the opinions are instructive as examples of how difficult it is for lower courts to apply the vague tests and standards enunciated there.

The courts first framed the issue as "whether the federal surface mining act is directed to the state as a sovereign entity, displacing its role as a decision-maker in areas of traditional governmental services, or whether the act is directed to private activity." ${ }^{\prime \prime 8}$ The courts recognized that the Act ultimately affected the coal mine operator, but held that the law's pervasive effect was "on the states' legislative authority and on state control of land within its boundaries." With the belief that land use planning is indisputably a state activity, the courts carefully and painstakingly reviewed the litany of "tests" announced in $\mathrm{Na}$ tional League of Cities and held that the SMCRA deprived the states of the power to decide how best to structure their own environmental protection plans. $^{80}$

In Hodel v. Virginia Surface Mining \& Reclamation Association, Inc. ${ }^{81}$ and Hodel v. Indiana ${ }^{82}$ a unanimous Supreme Court reversed

${ }^{73}$ The Secretary shall prepare and . . . promulgate and implement a Federal program for a State no later than thirty-four months after August 3, 1977, if such State-

(1) fails to submit a State program covering surface coal mining and reclamation operations by the end of the eighteen-month period beginning on August 3, 1977;

(2) fails to resubmit an acceptable State program within sixty days

of disapproval of a proposed State program . . ; or

(3) fails to implement, enforce, or maintain its approved State program as provided for in this chapter.

Id. $\S 504(\mathrm{a}), 30$ U.S.C. $\S 1254(\mathrm{a})$ (Supp. V 1981).

${ }^{74}$ Id. $\$$ 504(b), 30 U.S.C. \$ 1254(b) (Supp. V 1981) ("In the event that a State has a State program for surface coal mining, and is not enforcing any part of such program, the Secretary may provide for the Federal enforcement ... of that part of the State program not being enforced by such State.").

78483 F. Supp. 425 (W.D. Va. 1980), rev'd, 452 U.S. 264 (1981).

78501 F. Supp. 452 (S.D. Ind. 1980), rev'd, 452 U.S. 314 (1981).

77 See 483 F. Supp. at 431-35; 501 F. Supp. at 462, 464-65.

78 See 483 F. Supp. at 432 .

72 Id.

so Id. at 434.

s1 452 U.S. 264 (1981). 
the district courts insofar as they had found portions of the SMCRA unconstitutional and, for the first time since National League of Cities, elaborated upon the tenth amendment limitation on Congress's exercise of its commerce power.

First, the Court engaged in its traditional commerce clause analysis. The justices found ample rational basis for Congress's determination that surface mining adversely affects commerce among the states. ${ }^{83}$ In addition, the Court found that the statute's challenged provisions were reasonably related to the stated congressional purpose of controlling the adverse interstate economic and environmental effects of surface coal mining. ${ }^{84}$

Next, the Court noted that the lower court's heavy reliance on National League of Cities' vaguely stated rationale resulted in "an unwarranted extension of the decision in National League of Cities." Attempting to clarify the opaque standards and criteria discussed in National League of Cities, Justice Marshall, writing for the Court, formulated a three-pronged test for determining whether a federal statute enacted pursuant to the commerce clause violates the tenth amendment:

First, there must be a showing that the challenged statute regulates the "States as States." Second, the federal regulation must address matters that are indisputably "attribute[s] of state sovereignty." And third, it must be apparent that the States' compliance with the federal law would directly impair their ability "to structure integral operations in areas of traditional governmental functions."

Although the meaning of this test may be less than self-evident, in applying this test the Court at least explained what regulating the "States as States" meant. The Court rejected the tenth amendment challenge in Hodel because the provisions at issue in SMCRA governed directly only the activities of private individuals or businesses and not states qua states. ${ }^{87}$ National League of Cities did not limit the power of Congress to regulate private activities affecting interstate commerce,

82452 U.S. 314 (1981). Hereinafter both Hodel v. Indiana and Hodel v. Virginia Surface Mining $\&$ Reclamation Association, Inc. will be referred to collectively as Hodel. The Court in Hodel v. Indiana deferred to the decision in Virginia Surface Mining on the tenth amendment and commerce clause challenges to SMCRA. See 452 U.S. at $321-30$.

${ }^{83}$ Hodel, 452 U.S. at 281-82.

84 Id. at 283.

85 Id. at 284 . (1976)).

${ }^{86}$ Id. at 287-88 (quoting National League of Cities, 426 U.S. at $854,845,852$

${ }^{82} 452$ U.S. at 288. 
even if such federal regulation had the effect of displacing or preempt-. ing state regulation of these activities. As Justice Marshall observed, SMGRA does not directly coerce the states to enforce any standards, to expend any funds, or "to participate in the federal regulatory programs in any manner whatsoever." operative federalism that allows the States . . . to enact and to administer their own regulatory programs, structured to meet their own particular needs." 89 Because the statute failed to satisfy the first prong of Marshall's test, the Gourt did not even need to consider the second and third elements of the test.

Significantly, the Court also cautioned that "[d]emonstrating that these three requirements are met does not, however, guarantee that a Tenth Amendment challenge to congressional commerce power action will succeed." prongs of the Hodel test, it must further engage in a balancing of the federal interest involved against the state's interest in retaining its sovereignty: "the federal interest may be such that it justifies state submission."91 Thus, Justice Marshall, in the Court's opinion in Hodel, clearly adopted the balancing test that Justice Blackmun had advocated in his concurrence in National League of Cities. ${ }^{92}$

Finally, in response to the district court's finding that SMCRA displaces essential functions traditionally provided by the states, Justice Marshall stated that Congress could, pursuant to the commerce clause, decide to prohibit all state regulation of surface mining; "the Supremacy Clause permits no other result.",9s

Although Hodel's three-prong approach appeared to offer some improvement over National League of Cities' vague criteria, it could hardly be described as a litmus test for deciding federalism disputes. Rehnquist's ambiguous phrases, the subject of so much previous criticism, were adopted by Marshall verbatim. Although Marshall stated them more succinctly, they nevertheless remained "an abstraction without substance."94 It is hardly clear that any principled approach could guide the judiciary in its construction of such ambiguous terms as "traditional governmental functions," "integral operations," or "undoubted attribute of state sovereignty." Marshall simply quoted all

88 Id.

89 Id. at 289.

20 Id. at 288 n.29.

91 Id. (citations omitted).

92 In fact, Marshall specifically cited Blackmun's concurrence. Id. (citing, inter alia, National League of Cities, 426 U.S. at 856 (Blackmun, J., concurring)).

os Hodel, 452 U.S. at 290.

o National League of Cities, 426 U.S. at 860 (Brennan, J., dissenting). 
these phrases from National League of Cities without elaboration. ${ }^{85}$

Moreover, Hodel's adoption of the balancing approach proposed by Blackmun in National League of Cities as a "fourth" prong has disquieting similarities to the pre-1937 Court's adjudication of commerce clause cases generally. The pre-1937 Court always "balanced" in theory while engaging in unbridled policymaking in practice. When that Court disagreed with the policy embodied in a federal statute, it invalidated it and simply announced that the statute's effects on interstate commerce were too "indirect." test based on how direct the effect on commerce is, the "balancing test" enunciated in Hodel may also be considered a tool for unprincipled policymaking, providing after the fact justifications for arbitrary decisions. After all, balancing is not really a test but is rather a label for ad hoc decisionmaking unless the Court specifically enumerates what items go on which side of the scale, how much weight each item is accorded, and what principles of law are derived from the balancing.

Hodel's significance, however, is not its effort to add specificity to the vague tests of National League of Cities, but its unmistakable, symbolic message. It reaffirmed Congress's plenary power to regulate private entities under the interstate commerce power and therefore to preempt decisions of state and local governmental entities in order to further national goals. At least, Hodel establishes that National League of Cities is inapplicable when the federal government seeks to regulate private activities even if the effect of such regulation is to displace state regulation. Hodel, in short, restricts National League of Cities by holding that the tenth amendment does not limit "congressional power to pre-empt or displace state regulation of private activities affecting interstate commerce."97

\section{United Transportation Union v. Long Island Rail Road}

Less than a year after Hodel, the Supreme Court further restricted the scope of National League of Cities in United Transportation Union v. Long Island Rail Road. ${ }^{98}$ Specifically, the Court granted certiorari to decide whether the application to a state-owned railroad of Congress's acknowledged authority generally to regulate labor relations in the railroad industry would conflict with tenth amendment protections

${ }^{85}$ Hodel, 452 U.S. at 286-87 (quoting National League of Cities, 426 U.S. at $854,852,852,845$ ).

${ }^{26}$ See, e.g., Schechter Poultry Corp. v. United States, 295 U.S. 495 (1935); Railroad Retirement Bd. v. Alton R.R., 295 U.S. 330 (1935).

${ }^{97} 452$ U.S. at $289-90$ (emphasis added).

98455 U.S. at 678 (1982). 
of state sovereignty as enunciated in National League of Cities.99

The Second Circuit had declared the federal Railway Labor Act (RLA) ${ }^{\mathbf{1 0 0}}$ unconstitutional as applied to employees of the Long Island Rail Road (LIRR). ${ }^{101}$ It held that the operation of the LIRR, an enterprise owned by the state of New York, was an integral state governmental function ${ }^{102}$ and that the terms of the RLA usurped state authority over "essential governmental decisions." federal law impaired "the State's ability to structure employer-employee relationships in its role as sole provider of an essential public service." 104 Therefore, according to the court, the application of the federal statute to a state-owned railroad was inconsistent with the state sovereignty doctrine articulated in National League of Cities.

The Second Circuit decision, reached before the Supreme Court's clarification of National League of Cities in Hodel, underscores the degree to which states could rely on the broad rhetoric of the National League of Cities opinion to frustrate congressional exercise of the commerce power. Although dictum in National League of Cities supports the validity of federal regulation of state-owned railroads, ${ }^{108}$ the Second Circuit reached the opposite result.

The Second Circuit interpreted National League of Cities as requiring a two-tiered analysis under which a federal law would be unconstitutional if (1) it regulated a state activity that was "an integral or traditional government function," and (2) (following Blackmun's concurrence in National League of Cities) the state's interest in the activity outweighed the federal interest in regulating the activity. ${ }^{108}$ Thus, the Second Circuit initially had to determine "whether the operation of the railroad qualifie[d] as an integral or traditional government function."107 Finding that the operation of the state-owned railroad did so qualify, the Second Circuit then balanced the federal interest in regulating collective bargaining relations under the federal law against the state's interest under the New York Taylor Law. ${ }^{108}$ The court's ad hoc

99 Id. at 680 .

100 Railway Labor Act, ch. 347, 44 Stat. 577 (1926) (codified as amended at 45 U.S.C. $\S \S 151-188$ (1976 \& Supp. V 1981)).

101 United Transp. Union v. Long Island R.R., 634 F.2d 19 (2d Cir. 1980), rev'd, 455 U.S. 678 (1982).

102 Id. at $24-29$.

103 Id. at 25.

104 Id. at 20.

${ }^{103}$ National League of Cities, 426 U.S. at 854 n.18 (citing United States v. California, 297 U.S. 175 (1936)).

${ }^{108}$ Long Island R.R., 634 F.2d at 24.

107 Id. at 24-29.

108 N.Y. Crv. SERv. LaW $§$ 206-214 (McKinney 1983). 
conclusion was that the state's interest in controlling the operation of its railroad outweighed the federal interest in regulation of collective bargaining relations. ${ }^{108}$

Applying National League of Cities and the three-pronged test of Hodel, a unanimous Supreme Court reversed the Second Circuit and held that the tenth amendment did not prohibit application of the Railway Labor Act to a state-owned railroad engaged in interstate commerce. ${ }^{110}$ The Court focused on the third prong of the Hodel test "which examines whether 'the States' compliance with the federal law would directly impair their ability "to structure integral operations in areas of traditional governmental functions." "111 The Court noted that railroads had been subjected to comprehensive federal regulation of their operations and labor relations for nearly a century and that there was "no comparable history of longstanding state regulation of railroad collective bargaining or of other aspects of the railroad industry." "112 Moreover, the Court recognized a strong federal interest in favor of a uniform regulatory scheme governing railroad labor relations, concluding that such a scheme serves "to prevent disruptions in vital rail service essential to the national economy."113 The Court thus reaffirmed, by way of holding, its earlier dictum in National League of Cities that operation of a railroad in interstate commerce is not an integral governmental activity: "Federal regulation of state-owned railroads simply does not impair a state's ability to function as a state."114

\section{The Conditional Preemption Doctrine AND THE DIvided CourT}

\section{A. Federal Energy Regulatory Commission v. Mississippi}

If National League of Cities $v$. Usery ${ }^{116}$ created "islands in the stream of commerce"116 which are the exclusive province of the states, then Hodel v. Virginia Surface Mining and Reclamation Association ${ }^{\mathbf{1 1 7}}$ and United Transportation Union v. Long Island Rail Road ${ }^{\mathbf{1 1 8}}$ se-

${ }^{108}$ Long Island R.R., 634 F.2d at 30.

110455 U.S. 678 (1982).

111 Id. at 684 (emphasis added) (quoting Hodel, 452 U.S. at 288 (quoting $\mathrm{Na}$ tional League of Cities, 426 U.S. at 852)).

${ }_{112}$ Long Island R.R., 455 U.S. at 687-88.

113 Id. at 688.

114 Id. at 686 .

115426 U.S. 833 (1976).

11 Tribe, Federal-State Relations, in $4 \mathrm{~J}$. Choper, Y. Kamisar \& L. TRIBE, The Supreme Court: Trends And Developments 1981-1982, at 164 (1983).

117452 U.S. 264 (1981).

118455 U.S. 678 (1982). 
verely eroded the banks of those islands. National League of Cities may now stand for little more than the proposition that the federal government cannot eliminate the states as entities, ${ }^{119}$ set the wages of the governor and other integral state employees who are not engaging in a proprietary function, ${ }^{120}$ or move the state capital. ${ }^{121}$ Hodel and Long Island Rail Road demonstrate that very few aspects of state sovereign authority are immune from federal control. The next case in the postNational League of Cities era, Federal Energy Regulatory Commission v. Mississippi (FERC), ${ }^{122}$ reinforces that proposition, although its bare five-to-four majority suggests an uncertain future for tenth amendment limitations on federal power.

In FERC the Court upheld the federal Public Utility Regulatory Policies Act of 1978 (PURPA) ${ }^{123}$ against a challenge that the Act impermissibly encroached on state sovereignty in violation of the federalism principles announced in National League of Cities. PURPA was enacted as part of a legislative package designed to combat the thenperceived energy crisis plaguing the nation. ${ }^{124}$ PURPA, which governs regulatory policies for electrical and gas utilities, requires state public utility commissions to entertain various disputes under the federal regulations ${ }^{125}$ and to consider certain federal proposals in accordance with federally dictated procedures. ${ }^{126}$

In an unreported opinion, the District Court for the Southern District of Mississippi had held that PURPA was beyond the scope of congressional commerce clause power. ${ }^{127}$ In addition, the court had relied on National League of Cities in declaring that the statutory provisions were void as constituting "a direct intrusion on integral and traditional functions of the State of Mississippi."128 The Supreme Court unanimously reversed the lower court's holding with respect to the commerce clause issue, ${ }^{129}$ but a divided Court only narrowly rejected

11 See Maryland v. Wirtz, 392 U.S. 183, 196 (1968), overruled in other respects, National League of Cities v. Usery, 426 U.S. 833 (1976).

${ }^{120}$ National League of Cities v. Usery, 426 U.S. 833 (1976).

121 Coyle v. Oklahoma, 221 U.S. 559 (1911).

122456 U.S. 742 (1982). See generally Rotunda, Usery in the wake of Federal Energy Regulatory Commission v. Mississippi, 1 Const. Commentary 901 (1984).

123 Pub. L. No. 95-617, 92 Stat. 3117 (1978) (codified as amended in scattered sections of $15,16,30,42 \& 43$ U.S.C.).

124 PURPA \& 2, 16 U.S.C. § 2601 (1982).

128 Id. at $\S 210,16$ U.S.C. $\S 824 \mathrm{a}-3$ (1982).

${ }^{128}$ Id. at $\S 111,16$ U.S.C. $\S 2621$ (1982).

127456 U.S. at 752.

128 Id. at 753 (quoting Jurisdictional Statement, FERC, No. J79-0212(c) app. B at 8a-9a (S.D. Miss. Feb. 27, 1981) (final judgment of Judge Cox, the trial judge)). 129 The majority, consisting of Justices Blackmun, Brennan, White, Marshall, and Stevens, was joined on this issue by dissenting Justices Powell, Rehnquist, and 
the tenth amendment challenge. ${ }^{130}$

In an opinion written by Justice Blackmun, the Court easily concluded that the district court had erred in ruling that intrastate regulation of public utilities was not within Congress's plenary power over interstate commerce, because Congress had made a specific finding that "the regulated activities have an immediate effect on interstate commerce."131 In addition, Blackmun concluded that the legislative history of PURPA supported Congress's conclusion that federal regulations of natural gas and electricity retail sales, as well as a federal program for the promotion of conservation and efficiency in the use of facilities and resources by electric utilities, were necessary to ensure the continued viability of interstate commerce and the national economy. ${ }^{\mathbf{1 3 2}}$

Blackmun then addressed the tenth amendment issue in three parts, discussing each challenged provision of PURPA separately. He first considered two aspects of section 210 of the Act: ${ }^{133}$ (1) its preemption of certain state regulations, and (2) its enlistment of state authorities to enforce federal standards. In order to advance the goal of reducing consumption of fossil fuels, ${ }^{134}$ section 210 of the Act encouraged the development of cogenerators ${ }^{136}$ and small power facilities ${ }^{136}$ by preempting conflicting state regulations. ${ }^{137}$ After Hodel, the five person majority easily upheld this type of regulation. ${ }^{138}$ Section 210 also re-

O'Connor, and Chief Justice Burger. See id. at 771 (Powell, J., concurring in part and dissenting in part); id. at 775 (O'Connor, J., joined by Burger, C.J., and Rehnquist, J., concurring in the judgment in part and dissenting in part).

130 Id. at 758-71.

131456 U.S. at 755 (citing PURPA § 2, 16 U.S.C. § 2601 (1982) (congressional findings)).

132456 U.S. at $756-57$.

13316 U.S.C. $\$ 824 a-3$ (1982).

134456 U.S. at 750 .

138 "A 'cogeneration facility' is one that produces both electric energy and steam or some other form of useful energy, such as heat." Id. at 750 n.11.

138 "A 'small power production facility' is one that has a production capacity of no more than 80 megawatts and uses biomass, waste, or renewable resources (such as wind, water, or solar energy) to produce electric power." Id.

${ }_{137}$ Section 210(a) of PURPA directs FERC to promulgate regulations as are necessary to promote cogeneration and small power production. 16 U.S.C. \$ 824a-3(a) (1982). These regulations would preempt any conflicting state regulations. See Hodel v. Virginia Surface Mining and Recl. Ass'n, 452 U.S. 264, 290 (1981) ("A wealth of precedent attests to congressional authority to displace or pre-empt state laws regulating private activity affecting interstate commerce when these laws conflict with federal law." The Court goes on to say "that the Commerce Clause empowers Congress to prohibit all-and not just inconsistent-state regulation of such activities." The Court concludes stating that "the Supremacy Clause permits no other result.") (citations omitted).

138 456 U.S. at 759. Even Justice O'Connor, who was joined by Chief Justice Burger and Justice Rehnquist dissenting as to most of the majority's tenth amendment analysis, agreed that this preemption was constitutional. Id. at 775 n.1 (O'Connor, J., 
quired state authorities to enforce standards promulgated by FERC to promote cogeneration and small power production. ${ }^{138}$ The majority described this requirement of section 210 as "more troublesome."140 Nevertheless, the majority sustained it as a permissible constitutional directive to the states. ${ }^{\mathbf{1 4 1}}$ The Court reasoned that because Mississippi authorities "customarily engaged in" such adjudicatory activity already, section 210's requirement that state agencies implement and enforce FERG rules could not be seen as imposing any additional burden. ${ }^{142}$

Justice Blackmun found Testa v. Katt, ${ }^{143}$ decided in 1947, "instructive and controlling on this point." $144 \mathrm{He}$ described Testa as having made it clear that state courts were obliged, under the supremacy clause, to hear and enforce a plaintiff's claim under federal law. ${ }^{145}$ The federal statute in Testa provided for punitive damages and the state court had refused to enforce it as a "penal" law of a "foreign" sovereign. ${ }^{148}$ The United States Supreme Court reversed. The FERC majority quoted Testa to demonstrate that, because of the supremacy clause, "state courts do not bear the same relation to the United States that they do to foreign countries."147 The Court concluded that because of this special relationship, section 210 was constitutionally permissible. States have an obligation to enforce federal law. "Any other conclusion," it noted, "would allow the States to disregard both the preeminent position held by federal law throughout the Nation, . . . and the congressional determination that the federal rights granted by PURPA can appropriately be enforced through state adjudicatory machinery."148

Second, Blackmun turned to the provisions of titles I and III of PURPA, which required the states to "consider" federal standards dealing with rate structuring and other matters relating to the operation of electrical service. ${ }^{149}$ The majority noted that nothing in the rele-

dissenting in part).

139 PURPA § 210(f), 16 U.S.C. § 243a-3(f) (1982).

140456 U.S. at 759.

141 Id. at $759-61$.

142 Id. at 760 .

143330 U.S. 386 (1947).

144456 U.S. at 760.

${ }^{145} \mathrm{Id}$. at $760-61$.

146330 U.S. at 388.

${ }^{147}$ Id. at 389 , quoted in FERC, 456 U.S. at 763 n.28.

148456 U.S. at 760-61 (citing Martin v. Hunter's Lessee, 14 U.S. (1 Wheat.) 304, 340-41 (1816)).

149 PURPA $\$ \S 101-143,301-311,92$ Stat. 3117, 3120-34, 3149-54 (codified at 15 U.S.C. $\S \S 3201-3211$ (1982), 16 U.S.C. $\$ \S 2603-2644$ (1982), 42 U.S.C. $\$ \S 6801-6808$ (1976 \& Supp. V 1981)). See, e.g., PURPA \& 111, 16 U.S.C. § 2621 (1982) (requiring each state regulatory authority to consider the use of six different approaches to struc- 
vant statutory provisions compelled the states to enact regulations, nor did the Act mandate an agenda to which state decisionmakers must scrupulously adhere. ${ }^{150}$ Rather, the federal law simply conditioned "continued state involvement in a pre-emptible area on the consideration of federal proposals."161 As in Hodel, the Court allowed Congress to predicate continued state regulation in an area "on the condition"152 that the states "consider proposed [federal] regulations." "15s Congress, in short, "may impose conditions on the State's regulation of private conduct in a pre-emptible area,"154 and this proposition, not applicable to National League of Cities, ${ }^{165}$ allowed the Court to uphold PURPA without overruling National League of Cities. ${ }^{180}$

Third, Blackmun upheld those portions of titles I and III of PURPA that required state commissions to follow certain notice and comment procedures when acting on the proposed federal regulations. ${ }^{187}$ The Court noted that the procedural requirements simply established minimum due process guarantees already provided for by state law. ${ }^{108}$ Faced with the argument that the procedural requirements could therefore be upheld as an exercise of Congress's powers under section 5 of the fourteenth amendment to legislate commands to enforce procedural due process guarantees, ${ }^{\mathbf{1 5 9}}$ the Court did not reach that issue and instead opted to employ an analysis similar to that used in connection with the mandatory consideration provisions of titles I and III. ${ }^{160}$ The majority explained: "if Congress can require a state administrative body to consider proposed regulations as a condition to its continued involvement in a pre-emptible field-and we hold today that it can-there is nothing unconstitutional about Congress' requiring certain procedural minima as that body goes about undertaking its tasks." "161

turing rates, as well as mandating procedural requirements for their consideration).

180456 U.S. at 769.

181 Id. at 765 (emphasis added).

102 Id. (emphasis added).

108 Id. at 771 (emphasis added).

184 Id. at 769 n. 32 .

155 Id. at 765-66; see infra text accompanying notes 167-68.

156 Justice O'Connor's dissenting opinion found no meaningful distinction between the statutes at issue in FERC and National League of Cities. See infra text accompanying notes $167-68$ for a more detailed discussion of the important distinctions between the two cases:

167456 U.S. at $770-71$.

108 Id. at 770 \& n.34.

180 Id. at 770-71; see also J. Nowak, R. Rotunda \& J. Young, supra note 6, at $832-41$.

${ }_{160}$ Id. at 771.

161 Id.; see also Bishop v. Wood, 426 U.S. 341, 344 nn.6-7 (1976) (the government's power to create an interest carries with it the power over the procedures that 
What is troublesome about the FERC decision is that it was only a five-to-four decision. Even more troubling are the grounds on which the four justices dissented. The substance of the dissenting opinions includes theories and ideas which, if accepted, would result in the uprooting of present law and a return to much of the pre-1937 approach to judicial review.

Justice O'Connor authored the principal dissent, concentrating on the substantive holdings of the majority. Her conclusory statements, reminiscent of the pre-1937 approach of the Court, fail to provide any tests or guidance for future constitutional analysis.

With rhetorical flourish, Justice O'Connor accused the majority of "conscript[ing] state utility commissions into the national bureaucratic army,"162 of sanctioning the "dismemberment of state government,"16s of permitting Congress to "kidnap state utility commissions,"164 of making state utility commissioners "bureaucratic puppets of the Federal Government,"16s and of transforming state legislative bodies into "field offices of the national bureaucracy."166

Although Justice O'Connor likened PURPA to the statutory provisions at issue in National League of Cities, ${ }^{167}$ her analogy ignores the crucial distinction between the two cases that proved so important to Justice Blackmun. In the 1974 amendments to the Fair Labor Standards Act at issue in National League of Cities, Congress had not provided for conditional preemption: Congress simply told the states to pay their employees above a minimum wage. The states were given no choice. For example, although the federal government wanted the states to pay their hospital workers a certain wage, the federal government was not willing to take over-preempt-state hospitals to assure that the hospital workers were well paid. ${ }^{168}$ Although the federal government promulgated the regulations, only the states bore the cost of com-

surround the interest); Arnett v. Kennedy 416 U.S. 134, 153-54 (1974); Board of Regents v. Roth, 408 U.S. 564, 577 (1972).

${ }^{102} 456$ U.S. at 775 (O'Connor, J., joined by Burger, C.J., and Rehnquist, J., concurring in the judgment in part and dissenting in part).

103 Id. at 782 .

160 Id. at 790 .

$108 \mathrm{Id}$. at 783 .

106 Id. at 777.

107 Id. at $781-82$ \& n.9.

108 Under the tenth amendment, Gongress might not be able to take over the state police. Even assuming, however, that such is the case, the argument in the text would still apply to other state activities such as hospitals. Even as to state police, National League of Cities left open the possibility of reaching such activities under the spending clause. For example, Congress should be able to provide that state police paid in part with federal funds must be paid the minimum wage. 
pliance. ${ }^{169}$ The Court in National League of Cities in effect held that this cost-free arrangement in favor of the federal government would impermissibly burden the functioning of the state governments. ${ }^{170}$

Thus, the federal government in National League of Cities, without appropriating one federal dollar (even on a contingency basis), imposed a massive burden on the states. In FERC, on the other hand, the states had a choice: consider certain federal standards or the federal government will preempt the area. Therein lies the crucial distinction between National League of Cities and FERC, the distinction that the majority found dispositive. ${ }^{171}$ In $F E R C$ the federal government was willing to assume the substantial burdens preemption would impose on it in order to achieve the desired result. If the states did not wish to assume the new burdens imposed by the federal law, the states could opt out. The federal government would then come in, preempt the area-assuming the costs and burdens resulting from the regulation-and achieve its desired results directly.

Put simply, the federal government in National League of Cities told the states: "You pay the piper, but we'll call the tunes." In FERC the federal government said to the states: "You pay the piper and you call the tunes. We would like you to call certain tunes. If you refuse, then we will pay the piper and call the tunes."

If the federal government is willing to assume the full burdens of direct regulation it will not impose regulations without carefully considering the costs involved. ${ }^{172}$ The self-restraint imposed by the federal decisionmaking structure in FERC lessens the need for the type of active review in which the Court engaged in National League of Cities. As Justice Stone stated, in a slightly different context:

[T]he thought, often expressed in judicial opinion, [is] that when the regulation is of such a character that its burden falls principally upon those without the state, legislative action is not likely to be subjected to those political restraints which are normally exerted on legislation where it affects adversely some interests within the state. ${ }^{173}$

160 See National League of Cities, 426 U.S. at 846-48.

170 See id. at 846-52.

171 See supra notes $155-56$ and accompanying text.

172 J. Nowak, R. Rotunda \& J. Young, supra note 6, at 276-77; see also United States v. Carolene Prods. Co., 304 U.S. 144, 152 n.4 (1938); South Carolina State Highway Dep't v. Barnwell Bros., Inc., 303 U.S. 177, 184-85 n.2 (1938).

${ }_{123}$ South Carolina State Highway Dep't v. Barnwell Bros., Inc., 303 US. 177, 185 n.2 (1938). See also United States v. Carolene Prods. Co., 304 U.S. 144, 152 n.4 (1938) (Stone, J.). See generally J. Choper, Judicial Review and the National. Political Process (1980). 
Justice Stone used this argument to justify active Supreme Court review of state laws affecting interstate commerce as well as active review of state or federal laws restricting the Bill of Rights or burdening minorities. However, Stone recognized that this same rationale dictates a more restrained Supreme Court review of federal laws based on the commerce power. ${ }^{174}$ Such is the case in FERC. Conditional preemption provides a structural check on congressional decisionmaking which lessens the need for judicial activism.

Justice O'Connor's argument ignored this distinction between FERC and National League of Cities and instead questioned the acceptability of conditional preemption itself. Although O'Connor acknowledged that Congress can completely preempt the states in regulation of private conduct, ${ }^{175}$ she did not believe that Congress could conditionally preempt state regulation. ${ }^{176}$ She contended that Congress could not condition the validity of state enactments in a preemptible area on state conformity with federal standards. Such conditioning, she believed, would "coerce" the states into passing whatever legislation Congress might deem desirable. ${ }^{177}$

Justice O'Connor's argument, if accepted, would greatly expand the scope of the decision in National League of Cities. It would apply with equal force to the spending clause cases, which also involve a conditional exercise of federal power. ${ }^{178}$ Yet in the spending clause context,

174 See United States v. Carolene Prods. Co., 304 U.S. 144, 152-54 (1938). In Carolene Prods. Justice Stone noted that federal "regulatory legislation affecting ordinary commercial transactions is not to be pronounced unconstitutional unless in the light of the facts made known or generally assumed it is of such a character as to preclude the assumption that it rests upon some rational basis within the knowledge and experience of the legislators." Id. at 152. Stone added that where congressional judgment is drawn into question, "the inquiry must be restricted to the issue whether any state of facts either known or which could reasonably be assumed, affords support for it." Id. at 154.

${ }^{175} F E R C, 456$ U.S. at 775 n.1 (O’Connor, J., dissenting in part).

176 Id. at 781-87.

177 Id. at 785-91. The due process clause doctrine of unconstitutional conditions does not shield states from such coercion because states are not "persons" for purposes of the due process clause of the fifth amendment. South Carolina v. Katzenbach, 383 U.S. 301, 323-24 (1966).

${ }^{178}$ In Steward Machine Co. v. Davis, 301 U.S. 548 (1937), the Court sustained the unemployment compensation provisions of the Social Security Act. Congress had given the states a choice-either they could pass their own unemployment compensation programs, which had to meet federal standards, or the federal government would devise a program for them, preempting the area. The states were induced to form their own plans, instead of abandoning the area, through a provision of the tax imposed by title IX of the Social Security Act, which allowed the taxpayer a $90 \%$ credit against the federal tax for contributions made under a state unemployment law, provided that the state program met federal standards. The majority held that this "tax and credit" plan did not coerce the state and that no undue influence had been exerted by the national government on the state. See also Fullilove v. Klutznick, 448 U.S. 448, 474 (1980) 
the Court, even before 1937, consistently has recognized that federal grants may be designed to induce the states to comply with federal policy. ${ }^{179}$

Justice O'Connor objected that conditional preemption under the commerce clause "blurs the lines of political accountability."180 Yet, this "blurring" has not been regarded as justification for overturning the spending clause cases, cases with which $O^{\prime}$ Connor seems to agree. In 1983, in fact, Justice O'Connor wrote an opinion for a unanimous Court, which, in effect, accepted the rationale of conditional preemption. Bell $v$. New Jersey ${ }^{181}$ holds that if a state misuses funds advanced as part of a federal grant-in-aid program the federal government may recover those misused funds. The Court's reasoning in reaching this conclusion is significant:

Requiring States to honor the obligations voluntarily assumed as a condition of their ownership of funds simply does not intrude on their sovereignty. The State chose to participate in the Title I program and, as a condition of receiving the grant, freely gave its assurances that it would abide by the conditions of Title $\mathrm{I}^{182}$

Justice O'Connor's use of such language in upholding the conditional exercise of federal power in the spending clause context tacitly adopts the rationale of conditional preemption which she had criticized in her discussion of the relationship between the tenth amendment and the commerce clause in FERC.

Finally, Justice O'Connor's discussion of the application of the Hodel test ${ }^{183}$ to the FERC case exemplifies the dissent's focus on conclusory statements in place of helpful tests or explanations. For example, Justice O'Connor stated that "plainly [titles I and III of PURPA]

("Congress has frequently employed the Spending Power to further broad policy objectives by conditioning receipt of federal moneys upon compliance . . . with federal statutory and administrative directives. This Court has repeatedly upheld . . the use of this technique to induce governments and private parties to cooperate voluntarily with federal policy."); Oklahoma v. United States Civil Serv. Comm'n, 330 U.S. 127 (1947) (Federal highway funds could be conditioned on state's compliance with a provision of the Hatch Act. The state could remove the State Highway Commissioner who was also state chairman of the Democratic party or risk a cutoff of highway grants.).

178 See Oklahoma v. United States Civil Serv. Comm'n, 330 U.S. 127 (1947). See generally P. Hay \& R. Rotunda, The United States Federal System: Legal INTEGRATION IN THE AMERICAN EXPERIENCE 169-84 (1982).

${ }^{180}$ FERC, 426 U.S. at 787 (O'Connor, J., dissenting in part).

181103 S. Ct. 2187 (1983). See supra text accompanying notes 46-48.

$182103 \mathrm{~S}$. Ct. at 2197.

${ }^{183}$ See supra text accompanying notes 85-92. 
regulate the 'States as States.' "184 That conclusory statement, however, hardly provides a litmus test. The statute struck down in National League of Cities is directed against the states in the same way that the statute upheld in Bell $v$. New Jersey regulates the states as states: both require the states to spend money in a particular way or to refrain from spending money at all.

In order to satisfy the second prong of Hodel concerning "attributes of state sovereignty," O'Gonnor analogizes the situation in FERC to a congressional requirement that "state legislatures . . . debate bills drafted by congressional committees."185 That analogy, however, ignores the fact that $F E R C$ involves a state administrative agency, not a state legislature. Although Congress could not outlaw state legislatures, it could in effect outlaw state agencies regulating utilities by completely preempting the field. O'Connor attempts to dispose of the third prong in Hodel by simply announcing that "utility regulation is a traditional function of state government."188 Although Justice O'Connor candidly admits that the "Court has not fully explored the extent of 'traditional" state functions,"187 she then flatly asserts, without analysis, that "[u]tility regulation ... should fall within any definition of that term."188 The long history of federal regulation of utilities ${ }^{189}$ is conveniently ignored.

Finally, O'Connor fails to address the exception, mentioned in $\mathrm{Ho}$ $d e l$, of a federal interest so strong that it requires state submission despite satisfaction of all three prongs of the Hodel test. ${ }^{180}$ The FERC majority, finding that the three prongs of the Hodel test were not satisfied, did not have to 'reach this issue. Given O'Connor's conclusion, however, her dissent should have explained why the exception was inapplicable on the facts of FERC. ${ }^{191}$ Does such silence imply that the

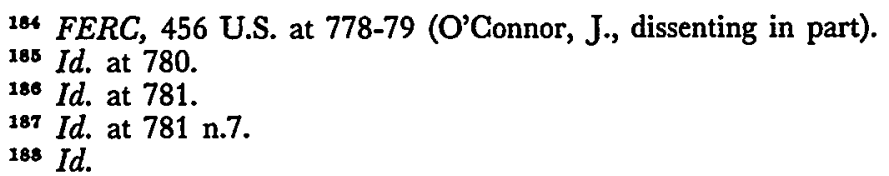

189 Such regulation includes tax subsidies, restrictions on business entry, antitrust policy, direct regulation of oil and gas prices, tariff and import and export restrictions, and energy allocation regulations. See generally T. Morgan, Cases And Materiars on Economic Regulation of Business (1976); W. Rodgers, JR., Cases and Materials on Energy and Natural Resources law (1979); H. Williams, R. Maxwell, \& C. Meyers, Gases and Materials on the Law of Oil and Gas (1974); Posner, Natural Monopoly and Its Regulation, 21 Stan. L. Rev. 548 (1969).

${ }_{100}$ Hodel, 452 U.S. at 288 n.29; see supra text accompanying notes 90-92.

191 Justice O'Connor does, in fact, recognize the exception, noting that both Hodel and Long Island R.R. adopted it. 456 U.S. at 778 n.4 (O'Connor, J., dissenting in part). She concludes, however, that "[n]either of these cases involved such an exception to National League of Cities and the Court has not yet explored the circumstances that might justify such an exception." Id. Certainly if she believed that the three prongs of 
dissent believed, as a matter of law, that there is no strong federal interest in energy policy? Such a view would lead to the implausible conclusion that Congress could not even "rationally" find a national energy problem to exist.

On a broader and more troubling note, the dissent resembles the Court's pre-1937 approach to judicial review of federal regulations: lengthy discussion of policy and little discussion of principles of constitutional adjudication. If accepted, the dissent's approach would result in certain areas being immune from federal regulation simply because five justices have labelled them to be "traditionally reserved to state authority."182

In a partial dissent, Justice Powell also expressed disagreement with the FERC majority's tenth amendment analysis. Although he described Justice O'Connor's dissenting opinion as "abl[e]"193 and applauded "the appeal-and indeed wisdom-of Justice O'Connor's evocation of the principles of federalism,"104 he concluded that the dissent's attacks on the constitutionality of the substantive provisions of PURPA were foreclosed by precedent. ${ }^{105}$ Nevertheless, Powell disagreed with the majority's conclusion regarding the procedural requirements of titles I and III. Powell rejected what he termed the majority's "threat of preemption" reasoning ${ }^{186}$ and warned that "[i]f Congress may do this, presumably it has the power to pre-empt state-court rules of civil procedure and judicial review in classes of cases found to affect commerce."197

Powell's reasoning fails to account for both longstanding precedent and the enabling provision of the fourteenth amendment. At best, he ignores section 5 of the fourteenth amendment which grants to Congress the power "to enforce, by appropriate legislation, the provisions of this article,"108 including the due process clause. The notice and comment procedures mandated by PURPA can be viewed as simply establishing minimum due process requirements for hearings conducted by state utility commissions. Viewed in such a light, the procedural requirements, if nothing else, should be a valid exercise of Congress's power to enforce due process guarantees under the fourteenth amendment. Implicit, therefore, in Powell's opinion is the contention that

the Hodel test were satisfied in FERC then the time was ripe for her to go exploring. ${ }^{192}$ FERC, 456 U.S. at 783 (O'Connor, J., dissenting in part).

193456 U.S. at 771 (Powell, J., concurring in part and dissenting in part).

194 Id. at 775.

198 Id. (citing Hodel and Testa).

198 Id. at 773.

107 Id. at 774.

198 U.S. ConST. amend. XIV, § 5; see supra text accompanying notes 157-60. 
Congress violates the tenth amendment if it compels states to enforce procedural due process (that is, rights to a hearing and notice) under the fourteenth amendment. It would appear that he is suggesting that the protections for states embodied in the tenth amendment limit the efficacy of the powers granted to Congress by the fourteenth amendment. Contrary to that suggestion, the purpose of the fourteenth amendment, which was enacted nearly three-quarters of a century after the tenth, was to limit state action and the powers of states under the tenth amendment, not vice versa.

To support his procedural argument, Powell cited Professor Henry Hart for the proposition that "federal law takes state courts as it finds them." "189 Hart did indeed make such a statement in 1954, but he noted that it was only the "general rule," and he also explained that the state rules must "not [be] so rigorous-as, in effect, to nullify the asserted rights." 200 Hart fully supported the case law which holds that states must provide a hospitable forum for the assertion of federal rights. ${ }^{201}$. The federal government has every right to expect that the states will fairly consider its proposals. Thus, Congress provided for basic procedural protections in PURPA to be sure that inadequate state procedures did not nullify federal rights.

The cases under the Federal Employers' Liability Act (FELA) ${ }^{202}$ are an old line of authority establishing that Congress does have the power to regulate state procedure in order to protect federal interests. For example, the Court has held that the seventh amendment, which guarantees a jury trial in a civil case in federal court, is inapplicable to a civil case brought in state court. ${ }^{209}$ Nonetheless, a state court hearing a FELA case cannot circumvent a litigant's federal right to a jury trial guaranteed by FELA, even though state law would have required that certain issues be decided by the judge rather than the jury-were it not for the federal act. ${ }^{204}$ In other words, a FELA plaintiff can choose a state forum but still have the benefit of certain federal procedures.

FELA also provides for a damage action by a railroad employee against his or her employer for occupational injuries caused by the neg-

309456 U.S. at 774 (Powell, J., concurring in part and dissenting in part) (quoting Hart, The Relations Between State and Federal Law, 54 Golum. L. Rev. 489, 508 (1954)).

200 Hart, supra note 199, at 508.

201 See Williams v. Georgia, 349 U.S. 375, 399 (1955) (Clark, J., dissenting); see also Hart, The Time Chart of the Justices, 73 HARv. L. REv. 84, 116 (1959).

20245 U.S.C. $\$ \S 51-60$ (1976).

203 Minneapolis \& St. L. R.R. v. Bombolis, 241 U.S. 211 (1916).

204 Dice v. Akron, C. \& Y.R.R., 342 U.S. 359, 362-64 (1952). 
ligence of the railroad ${ }^{205}$ and allows for a survivor's action in the event that negligence results in the employee's death. ${ }^{206}$ Thus, FELA preempted state common and statutory law in interstate railroad employer's negligence cases. ${ }^{207}$ State courts hearing such cases must not only apply federal substantive law but also federal procedural guarantees when those procedures are found by Congress to be a substantial part of the rights accorded by FELA. ${ }^{208}$ One such procedural guarantee is the right to a jury trial; thus, Court decisions after the 1939 amendments ${ }^{209}$ to FELA "teach that the Congress vested the power of decision in these actions exclusively in the jury in all but the infrequent cases." 210

The FELA cases demonstrate that Congress can dictate certain procedural requirements for federal civil cases brought in state court. Congress is able to mandate these procedures in order to ensure that the federal interest in providing a cause of action for certain injured workers is protected. If Congress can mandate such procedures in order to affect the substantive outcome of a case brought in a state trial court, it should be able to mandate similar procedures in proceedings brought before state agencies.

Curiously, Justice Powell failed to mention the FELA precedents and the role of conditional preemption, just as he ignored the implications of section 5 of the fourteenth amendment. Acceptance of his opinion, therefore, would result in the rejection of longstanding precedent as well as adoption of an illogical interpretation of the Constitution.

${ }^{20 s} 45$ U.S.C. $\S 51$ (1976). See, e.g., Chambers v. Chicago, B. \& Q.R., 138 Neb. 490, 490, 293 N.W. 338, 339 (1940). In Chambers the court states that:

Liability imposed by the Federal Employers' Liability Act is liability for negligence of common carrier for damages to any person suffering injury while in the employ of such carrier in commerce between states, resulting, in whole or in part, from the negligence of the officers, agents, or employees of such carrier.

Id. (syllabus by the court).

${ }_{200} 45$ U.S.C. $\$ 59$ (1976). See, e.g., Washington Ry. \& Elec. v. Scala, 244 U.S. $630,638-40$ (1917) (Affirming a lower court ruling against the railroad, the Supreme Court allowed plaintiff's decedent damages for pain and suffering of deceased. Court held that plaintiff stated a case of negligence plainly within the terms of the Federal Employers' Liability Act and made a valid claim for the death of deceased from injuries which caused him to "suffer intense pain.").

${ }^{207}$ South Buffalo Ry. v. Ahern, 344 U.S. 367 (1953).

208 See, e.g., Dice v. Akron, C. \& Y.R.R., 342 U.S. 359, 363 (1952) (jury trial).

209 Act of Aug. 11, 1939, ch. 685, 53 Stat. 1404 (codified as amended at 45 U.S.C. $\S \S 51-60$ (1976)).

210 Rogers v. Missouri Pac. R.R., 352 U.S. 500, 510 (1957) (footnote omitted). See also Baltimore \& O.R.R. v. Davis, 379 U.S. 671 (1965); Dennis v. Denver \& Rio Grande W.R.R., 375 U.S. 208 (1963); Basham v. Pennsylvania R.R., 372 U.S. 699 (1963); Brown v. Western Ry., 338 U.S. 294 (1949) (state rule regarding particularity in pleadings cannot be used to defeat FELA liability). 


\section{B. EEOC v. Wyoming}

The Court's most recent opportunity to refine National League of Cities was its decision in EEOC $v$. Wyoming. ${ }^{211}$ In that case, the trial court invalidated the extension of the Age Discrimination in Employment Act (ADEA) ${ }^{212}$ to employees of state and local governments, specifically Wyoming game and fish wardens. ${ }^{213}$ The ADEA forbids discrimination against any potential or present employee between 40 and 70 years old on the basis of age, unless "age is a bona fide occupational qualification reasonably necessary to the normal operation of the particular business, or where the differentiation is based on factors other than age."214 In the trial court, Wyoming had successfully argued that its mandatory retirement age of 55 was necessary to assure the physical preparedness of its game wardens. ${ }^{218}$ The Supreme Court, in another five-to-four opinion, ${ }^{216}$ reversed and held that the commerce power justified the extension of the federal Act. ${ }^{212}$

Justice Brennan, who had dissented in National League of Cities, wrote the majority opinion. He readily conceded that the federal law prohibiting discrimination in employment based on age did regulate the "States as States," the first part of the three-part Hodel test, but then he noted, by way of footnote, that this prong of the Hodel test marks National League of Cities as "a specialized immunity doctrine rather than a broad limitation on federal authority."218

The majority had "significantly more difficulties"219 with the second prong of the Hodel test-the determination whether the statute affected an "undoubted attribute of state sovereignty"220_-because, the Court candidly admitted, "[p]recisely what is meant by an 'undoubted attribute of state sovereignty' is somewhat unclear . . . and our subse-

211103 S. Ct. 1054 (1983).

21229 U.S.C. $\$ \S 621-634$ (1976 \& Supp. V 1981).

213 EEOC v. Wyoming, 514 F. Supp. 595 (D. Wyo. 1981), rev'd., 103 S. Ct. 1054 (1983).

214 Age Discrimination in Employment Act of 1967 \& 4(f)(1), 29 U.S.C. $\S$ 623(f)(1) (1976).

213 EEOG v. Wyoming, 103 S. Ct. at 1062.

216 Chief Justice Burger, joined by Justices Powell, Rehnquist, and O'Connor dissented. Id. at 1068. Justice Stevens joined the Court's opinion, but also wrote a separate concurrence arguing that National League of Cities should be overruled. Id. at 1064.

${ }^{217}$ Id. at 1064 (opinion of the Court). The Court did not find it necessary to reach the question of Congress's power under section 5 of the fourteenth amendment, but noted that the constitutionality of congressional action need not depend on Congress's recitals of the origins of the power. Id. at n.18.

${ }^{218}$ Id. at 1061 n.10.

219 Id. at 1061 n.11.

220 National League of Cities, 426 U.S. at 845. 
quent cases applying the National League of Cities test have had little occasion to amplify on our understanding of the concept."221 The Court did not need to apply or explore the meaning of this amorphous concept, however, because it concluded that the ADEA did not meet the third prong of the Hodel test: it did not "'directly impair' the State's ability to 'structure integral operations in areas of traditional governmental functions." "222

In reaching this conclusion, Justice Brennan reasoned that, under the federal law, Wyoming could meet its goal of physical preparedness simply by proceeding in a more individualized manner and only dismissing those wardens who are insufficiently fit. ${ }^{223}$ Alternatively, it could keep its present policy by demonstrating that age is a bona fide occupational qualification for the job. ${ }^{224}$ Finally, the majority could find no reason to conclude that the federal law at issue would have any "wide-ranging and profound threat to the structure of State governance." 228

In National League of Cities the Court had concluded that imposing the federal minimum wage on state workers would significantly affect state budgeting decisions regarding vital programs. The EEOC $v$. Wyoming Court held that the analysis of the impact of federal law on the state budgetary process is not an empirical study. Rather, it is a "generalized inquiry, essentially legal rather than factual, into the direct and obvious effect of the federal legislation on the ability of the States to allocate their resources." found that the ADEA would not have results similar to the statute in National League of Cities:

In this case, we cannot conclude from the nature of the ADEA that it will have either a direct or an obvious negative effect on state finances. Older workers with seniority may tend to get paid more than younger workers without seniority, and may by their continued employment accrue increased benefits when they do retire. But these increased costs, even if they were not largely speculative in their own right, might very well be outweighed by a number of other factors: Those same older workers, as long as they remain employed, will not have to be paid any pension benefits at

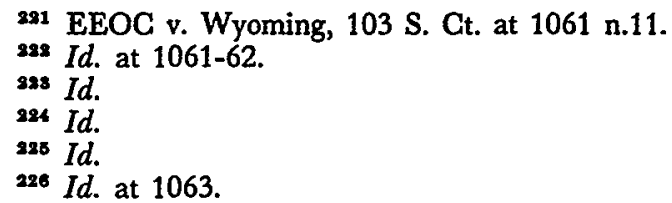


all, and will continue to contribute to the pension fund. And, when they do retire, they will likely, as an actuarial matter, receive benefits for fewer years than workers who retire early. ${ }^{227}$

The same four justices who had dissented in FERC also dissented in EEOC v. Wyoming. ${ }^{228}$ Chief Justice Burger authored the opinion which argued that the ADEA violated the principles enunciated in $\mathrm{Na}$ tional League of Cities and refined in Hodel. ${ }^{229}$ Burger dismissed the conclusions of the majority ${ }^{230}$ that Wyoming, without undue burden, could pursue its goals without a mandatory retirement age ${ }^{281}$ and that the bona fide occupational qualification defense provided the state with a meaningful alternative. ${ }^{232}$ Burger then addressed the "fourth" prong of Hodel: the balancing advocated by Justice Blackmun in his National League of Cities concurrence. Describing the federal interests involved in EEOC v. Wyoming as "largely theoretical" and the state interests involved as "real," the Chief Justice asserted that the "Commerce Clause powers are wholly insufficient to bar the states from dealing with or preventing these [real] dangers in a rational manner."2ss

Burger then turned to the question whether the ADEA could be upheld as an exercise of Congress's power under section 5 of the fourteenth amendment. He did not believe that section 5 could justify the application of the ADEA in EEOC $v$. Wyoming, an issue the majority did not need to reach. ${ }^{234} \mathrm{He}$ also found it important that there is "no hint in the body of the Constitution ratified in 1789 or in the relevant amendments that every classification based on age is outlawed."288s

Significantly, only two of the justices, Justice Powell, ${ }^{238}$ joined by Justice O'Connor, wrote to object to the concurrence of Justice Stevens which had bluntly urged that National League of Cities be overruled. ${ }^{\text {ss7 }}$

222 Id. (footnote omitted).

${ }^{228}$ Id. at 1068 (Burger, C.J., dissenting, joined by Powell, Rehnquist \& O'Connor, JJ.).

220 Id. at 1068-71.

230 See supra text accompanying notes 223-25.

281 EEOC v. Wyoming, 103 S. Ct. at 1071 (Burger, C.J., dissenting).

232 Id. at 1071-72.

$23 s$ Id. at 1072.

286 Id. at $1072-74$.

2ss Id. at 1074.

2se Id. at 1075 (Powell, J., joined by O'Connor, J., dissenting).

${ }^{237}$ Id. at 1064 (Stevens, J., concurring). 


\section{Conclusion}

After Federal Energy Regulatory Commission v. Mississippi, ${ }^{238}$ the future of National League of Cities $v$. Usery ${ }^{238}$ is unclear. Certainly FERC may read as a continuation of the Court's narrowing of National League of Cities. The narrow majority of justices who voted to uphold the statute in FERC, however, suggests the growing reluctance of several justices to continue this trend. With one additional vote, the four dissenters in FERC and EEOC v. Wyoming ${ }^{240}$ would command a majority of the Court. Whether a future court will resuscitate the tenth amendment analysis of National League of Cities in order to substitute its economic judgments for those of Congress in a way reminiscent of the pre-1937 Court is an open question. Four of the justices in FERC thought that case was akin to National League of Cities and regarded the federal regulation as invalid. ${ }^{241}$ Four justices upheld the federal regulation, but they also thought that National League of Cities had been wrongly decided. ${ }^{242}$ Only one member of the Court thought that both National League of Cities and FERC were correctly decided. ${ }^{243}$

There is nothing inherently wrong with the judicial technique of balancing interests to reach a decision when that balancing leads to some definable rule or test. When, however, the purported balancing fails to yield any principle that will facilitate the understanding and guide the actions of lower courts, we are left merely with ipse dixits by judicial Caliphs. Henry Hart noted long ago that in the end:

[I]pse dixits are futile as instruments for the exercise of "the judicial Power of the United States." As such, they settle little or nothing more than the case in hand, and attempted rationalizations of them serve more often to create than to relieve doubts in other cases. . . .

... Only opinions which are grounded in reason and not on mere fiat or precedent can do the job which the Supreme Court of the United States has to do ... [because that Court does not] have the power either in theory or in practice to ram its own personal preferences down other peo-

238456 U.S. 742 (1982).

289426 U.S. 833 (1976).

240103 S. Ct. 1054, 1068 (1983).

O'Connor.

241 The four were Chief Justice Burger and Justices Powell, Rehnquist, and

242 The four were Justices Brennan, White, Marshall, and Stevens who joined the FERC majority and dissented in National League of Cities.

243 This was, of course, Justice Blackmun. 
ple's throats. ${ }^{244}$

The decision in National League of Cities precipitated precisely this situation. Lower courts and commentators could not decipher the message of the High Court. Confusion reigned until the Court provided some clarification in Hodel $v$. Virginia Surface Mining and Reclamation Association, Inc. ${ }^{245}$ and United Transportation Union $v$. Long Island Rail Road. ${ }^{246}$ Yet, given the frail majority in FERC and the fact that parts of the Court's opinion were written quite narrowly, the possibility exists that one justice may simply change his or her mind on slightly different facts. ${ }^{247}$ In many ways the Court seems to have regressed to the chaotic period immediately following National League of Cities.

To add to this confusion, some commentators have already interpreted $F E R C$ unusually narrowly. $F E R C$ is correctly read as holding that Congress may impose conditions upon continuation of state regulation in any field that is federally preemptible. As such, $F E R C$ usefully limits National League of Cities. The latter case is distinguishable from FERC simply because no such conditional preemption was involved. Yet one commentator has, surprisingly, argued that such an interpretation of FERC would be misleading and would, in effect, overrule $\mathrm{Na}$ tional League of Cities. ${ }^{248}$ One report of his views indicates that he believes that the FERC Court actually only meant that:

state agencies may be required to settle disputes about federal regulations that are analogous to those state disputes they already handle and to consider (not adopt) federal proposals in accord with federal procedures that simply broaden participation a bit beyond that prescribed by state procedures, because such conditions are both minimally intrusive and fully consistent with federalism's underlying value of broader local participation in government. ${ }^{248}$

244 Hart, supra note 201, at 98-99.

245452 U.S. 264 (1981).

248455 U.S. 678 (1982).

247 See FERC, 456 U.S. at 747-48. If the statute had provided for penalties or had required the state to adopt federal standards, would the case come out differently for Blackmun? Surely Congress ought to be able to say: adopt these federal standards or the federal government will preempt the area. As Justice Blackmun did state in one portion of his opinion, "[s]o long as the field is preemptible-the nature of the condition is [ir]relevant." Id. at 767 n.30.

${ }_{248}$ See Supreme Court Review and Constitutional Law Symposium, 51 U.S.L.W. 2248 (Oct. 26, 1982) (reporting a speech made by Professor Tribe).

2* Id. (emphasis in original). See also Tribe, Federal-State Relations, in $4 \mathrm{~J}$. Choper, Y. Kamisar, \& L. Tribe, The Supreme Court: Trends and DevelopMENTS 1981-1982, at 167 (1983). 
This view of the decision reflects more of the O'Connor dissent than the majority analysis.

A proper reading of $F E R C$ significantly cabins National League of Cities. Basically, National League of Cities stands for the limited proposition that federal law cannot eliminate the states, set the salary of the state governor and other somewhat similar state workers, or move the state capital. If Congress can preempt an area of regulation, the proper reading of FERC allows it instead to condition the state's continued participation and involvement in the area on state acceptance of the federal requirements. ${ }^{250}$ The interpretations of congressional power expressed in the dissenting opinions in FERC and EEOC $v$. Wyoming differ radically from those of the majority. The FERC and EEOC v. Wyoming dissents invite the Court to return to its pre-1937 legacy and, in the guise of constitutional analysis, invalidate economic policy with which it disagrees.

As Justice Blackmun recognized in $F E R C$, the doctrine of conditional preemption provides a principled justification for congressional exercises of the commerce power that may be seen by some as infringing on the traditional domain of state governments. Rather than returning to ad hoc review of economic legislation, which invites judicial encroachment on the policymaking role of the legislative branch, the Court should follow the course staked out by the doctrine of conditional preemption. Such a course is consistent with the requirements of the Constitution, ensures carefully deliberated federal decisionmaking by

250 Professor Tribe's reasoning was described as follows:

If the federal government may tell the states how to conduct their governmental activities so long as the field of law is one which Congress could substantively pre-empt at will, then it could require the states to pay their highway commissioners and toll-takers a federal minimum wage as a condition of operating state highways, inasmuch as Congress could surely pre-empt all highway operations. Yet that intrusion into state sovereignty was the very one that National League of Cities struck down.

51 U.S.L.W. at 2248. However the hypothetical instruction is quite different from that which existed in National League of Cities: in National League of Cities there was no conditional preemption, while in the hypothetical (as in FERC) there is. As long as the federal government is committed to take over a preemptible area of governance under the terms it sets for the states, the decision made at the federal level should be wellconsidered and the scheme of regulation consistent with the federalism of the United States Constitution. 
the intrinsic characteristics of the regulation it allows, and provides meaningful guidance to lower courts that must analyze future cases. 
